\title{
Everybody's Artist Photographer: Collaborators and creative influences in the work of Charles Peet Dawes
}

A profile commentary by Keith Giles

Keywords: \# New Zealand \# Photography \# Dawes \# Dog Tax War \# Hokianga\# Kohukohu

When 1670 glass plate negatives taken by Kohukohu photographer Charles Peet Dawes were gifted to Auckland Libraries in 2018, it was immediately obvious from annotations on the negative envelopes that established ideas of how and when Charlie took up photography needed to be re-examined. Charlie's notes also revealed the names of some previously unsuspected Hokianga visitors and residents who influenced and assisted him in his artistic endeavours. In addition, buried in the collection was a unique record of the 1898 Dog Tax Rebellion together with invaluable and historically important photographs of the people and communities of the Hokianga at the end of the nineteenth century and the beginning of the twentieth. 
In October 2018 Auckland Libraries' Sir George Grey Special Collections received a large donation of glass plate negatives that had been taken by the Hokianga-based photographer Charles Peet Dawes (1867-1947) in the final years of the nineteenth century and the first decades of the twentieth. Although it is not unusual for the Library to receive donations of this type of negative, more often than not such donations comprise just one or two glass plates, or very occasionally a box of ten or twelve. What was different about this donation was its sheer size 1670 negatives in total.

At the time of the donation the Sir George Grey Special Collections was already home to some 475 glass plates taken by Charlie Dawes that were found in a secondhand shop in Kaitaia in 2012. In addition thirteen quarter plate Maori portraits discovered in an Upper Queen Street junk store in the 1970s and gifted to the Library in 2010 were identified as the work of Charlie Dawes during research for the Library's 2013 exhibition of Maori taonga, Manatunga. Together the three collections total over 2100 photographs, the largest assemblage of Dawes material anywhere in New Zealand.'

Charles Peet Dawes lived most of his life in the Hokianga, but was born in the small town of Swadlincote, on the outskirts of Burtonon-Trent, England in 1867. The eldest son of Ann Peet and Samuel

Dawes, he came to New Zealand with his parents and two siblings Ernie and Sarah Alice on the Boyne, arriving in Lyttelton in February 1879. Many of the ship's passengers were bound for Timaru, and it seems likely that this was also the planned destination of the Dawes family before they were side-tracked by the 1886 Special Village Settlement Scheme which took them first to Punakitere near Taheke (just inland from Rawene) and then on to Kohukohu. It was here in 1901 that Charlie married Jessie Allen (nee Bryers, the widow of William Mcllreen Allen), with whom he had five children Rachel Peet (1902), Ada Ann (1903), Christina May (1904), Pearl (1907), and Abner Earle (1908). ${ }^{2}$

The Kaitaia negative cache had permitted a number of conclusions to be drawn about Charlie's family and his photographic activities; most notably it had provided an approximate date for Charlie's first forays into photography. One group portrait in particular [negative 1142-D88] was identified by descendants as the wedding of Bessie Magee to George William Alexander Phillips at Oue (between Rawene and Waima) in 1892, and it seemed probable that this was one of the first, if not the earliest, of Charlie's photographs. But a glass plate in the 2018 donation directly challenged this assumption. This was negative number 1572-1115 (figure 1) which showed two boys and a young man resting by a tree stump, with sacks or hessian kits at their feet. The negative was protected from damage by its own negative envelope, part of a re-purposed sheet of newspaper on which had been written "Ernie, Jack \& Dugmore $1^{\text {st }}$ attempt". The surname Josephs had been added in pencil at a later date above the name Jack. This was clearly Charlie's brother-in-law Edwin Dugmore, their friend Jack Josephs, and Charlie's brother Ernie; "1st attempt" must surely mean that this was Charlie's first ever effort at taking a photograph. The newspaper was imprinted with the date 1888, at which time Ernie would have been 14 and Jack Josephs a year younger, ${ }^{3}$ plausible ages for both boys in the photograph, and pushing Charlie's photographic endeavours back another 4 years, from 1892 to 1888 .

Like many settlers along the Hokianga, Charlie combined a number of jobs to make a living. He worked variously as a night soil collector, carrier, and mailman; ${ }^{4}$ and a handful of business flyers among the 2018 donation are incontrovertible evidence that Charlie also operated as a professional photographer. Despite his hand-outs being printed by the Hokianga County Times which began publication only in $1905,{ }^{5}$ and although his first trade listing as a photographer appeared in the 1900 New Zealand Post Office Directory, ${ }^{6}$ essentially there was no reason to doubt that the 1892 Magee-Philips wedding portrait was taken in a professional capacity, and very early on in Charlie's professional career. In apparent confirmation of this fact the first of the 1670 glass plate negatives to be cleaned in December 2018 [negative 1572-953, figure 2] turned out to be a photograph of the Kohukohu waterfront complete with a photographer's signboard near the boatsheds at the eastern end of the town quay. The immediate assumption was that this had to be the location of Charlie's studio. But on further examination it became obvious that this photograph was taken after 1900 when the original Kohukohu Hotel was destroyed by fire, and after Charles and Robert Lester had ceased cultivation of the terraces above. Since there were other photographers working in the area in the early 1900 s, most notably the Northwood Brothers who were active in Northland from at least 1903/4, ${ }^{7}$ it was impossible to say with any certainty that these were Charlie's premises. Indeed although Charlie may have been taking photographs from 1888, as each of the negatives was investigated there was a creeping realisation that he may not have regarded himself as a professional photographer until much later.

Some of Charlie Dawes' best known photographs are of the Dog Tax Rebellion which broke out in Waima and Rawene in May 1898. There are around 50 of them in total forming a unique record of this 
little-known episode in New Zealand history. One of the photographs apparently from that event is a distant view of the church at Waima and surrounding buildings which was printed in the New Zealand Graphic of 28 May 1898. The original negative [1572-350, figure 3] forms part of the recent donation, and although the published version retained Charlie's name as it appeared in the bottom right-hand corner of the glass plate, it omitted the qualifying wording below the signature: "Amtr Photo". There are other negatives in the collection with the same annotation, such as $1572-438$ which, according to a pencil note on its envelope, was taken "around 1890" and shows a view of the Rawene main street looking down towards the wharf from above Bryers' Masonic hotel. Negative 1572-437, a view of the Rakauwahi Falls, has the same notation. There can be little doubt that this abbreviation must stand for "Amateur Photo" or "Amateur Photographer".

But why did Charlie feel it necessary to add this qualification? Other negatives in his Dog Tax Rebellion sequence are inscribed with his name, the date of the photograph and the word "Protected" (occasionally shortened to "Protd") in accordance with the provisions of the 1896 Photographic Copyright Act. Its counterpart, the 1877 Fine Arts Copyright Act, had granted legal protection to artworks and photographs for the life of the artist or photographer plus seven years, but only on payment of a fee and only from the date of registration. The 1896 Act provided for a copyright period of just five years in total, but the legal protection was instantaneous and cost nothing - important considerations where photographs were of topical significance and the photographer's income was restricted. Of course, this does not in itself explain why Charlie chose to flag his amateur status on some negatives and not others, but a reasonable interpretation would be that his use of the term "Amtr" essentially pre-dated the events at Rawene and was superseded by the formula prescribed by the Photographic Copyright Act on the recommendation of someone in the trade.

The likely source of this invaluable piece of advice was the Onehunga photographer Enos Sylvanus Pegler. Negative 1572-1220 (figure 4) shows him alongside Charlie in front of a photographer's tent or booth with Pegler holding a camera and Charlie standing next to a sample board. Two large banners read "Everyone's artist photographer" and "Your photograph while you wait". The negative is undated and the location is unknown, but the surrounding foliage suggests the photograph was taken in the Hokianga area. There is no record of how their association came about, but it is possible to make some suppositions.
Newspaper evidence is proof that Pegler was working as a photographer in Onehunga from at least 1891, if not earlier, ${ }^{8}$ and a weekly passenger ship service inaugurated between Onehunga and Kohukohu in 1886 would have provided Charlie with a direct link to the Manukau Harbour and facilitated their acquaintance. Indeed there are several photographs in the Dawes collection inscribed with the same distinctive scratchy lettering apparent in Charlie's photograph of Waima that would suggest he made the trip south; in particular negatives $1572-987$ and $1572-990$ form a two-part panorama of the Onehunga waterfront, while negative 1572-988 is a view of Mangere Mountain with Charlie himself crouched in the foreground. In addition there are at least two other Onehunga connections: in 1902 Charlie's brother Ernie married Annie Charlotte Walker of Onehunga, ${ }^{10}$ and it seems probable that Charlie would have known the town's mayor, Dr William Close Erson who accompanied the expeditionary force to Rawene during the Dog Tax Rebellion and features in several of Charlie's photographs. In a further link with the district Charlie's relatives Tom and Ann Smith lived in Waiuku across the harbour from Onehunga.

Equally it is evident from photographs published in the New Zealand Graphic and Auckland Weekly News that Enos Pegler had visited the Hokianga at some point in the $1890 \mathrm{~s}$. Both publications printed Pegler photographs of the area in their editions dated 14 May 1898 , although the likelihood is that these were taken much earlier and should be construed as an example of Pegler supplying stock photographs to meet the sudden Press interest in the region. In fact an "S Pegler" (apparently Enos masquerading under his second name Sylvanus) is recorded as having presented a limelight lecture entitled "A trip to the North" at a meeting of the Onehunga Mutual Improvement Society in August 1890 in which specific mention was made of the lecturer having visited Rawene, Kohukohu and Taheke." Even if Charlie and Enos had previously met in Onehunga the expedition would have provided the perfect occasion to renew their relationship, and the envelope for negative 1572-1614 - a group portrait of the extended Dawes family, including babe-in-arms Charles Edwin Dugmore who was born in January 1890 - is captioned "Our Group (Vanus took)", the use of what appears to be a truncated form of Sylvanus seemingly confirming that this was in fact what happened.

The Dog Tax Rebellion was a major news event, the climax of Maori opposition in the Hokianga to dog registration and tax. The conflict escalated as Richard Seddon's government rushed troops and a gunboat from Auckland to the Hokianga. Amongst the rumblings 
of war Pegler clearly spotted an opportunity to make some money beyond simply selling items from his back catalogue. In May 1898 he advertised that he had engaged a local photographer to record the unrest, ${ }^{12}$ and the Dawes connection suggests that his man on the ground was probably Charlie. Of the 50 or so photographs that Charlie Dawes took of the proceedings, his portrait of the arrested men [1572425, figure 5] is perhaps the most well-known. The general high quality of the images, however, did not prevent a rather disparaging comment from an Auckland Weekly News reporter who complained about a loca photographer getting in the way of the arresting officers. ${ }^{13}$

So did Charlie learn his photography from Enos Pegler? Quite possibly, although the photograph of Charlie and Enos together outside their tent has the appearance of equals rather than pupil and teacher; and Pegler was not the only photographer Charlie seems to have collaborated with. The presence of several varnished negatives in the collection (an early technique used to protect the negative) suggests that he received instruction in photography from someone with wetplate experience, and there are a couple of references in the collection to a mysterious Mr Warren. According to notes on their envelopes, negatives $1572-89$ and 1572-90 were taken in Warren's studio by $\mathrm{Mr}$ Warren, and negatives $1572-444$ and $1572-445$ were taken using a 3D portrait lens that Charlie borrowed from Mr Warren in May 1906. The puzzle of Warren's identity is solved by three portraits labelled "D M Warren" among the Dawes material that was recovered from Kaitaia in 2012. Warren turns out to be Daniel Mapowder Warren who ran a photographic studio in Carlyle (Patea) in the 1870 s and $1880 \mathrm{~s},{ }^{14}$ and by the early 1900 s was working as a gardener in Kohukohu. ${ }^{15}$

Another photographer with whom Charlie seems to have had contact is the Wellington businessman Henry Wright. Wright is known to have visited Kohukohu in 1893 to 1894, perhaps on more than one occasion, ${ }^{16}$ and at least 34 negatives taken by him can be found among the Dawes Collection. Charlie marked just two of them as specifically being "Wright's negatives", but some are recognisable by the initials HW (not to be confused with the Auckland photographer Henry Winkelmann) in one corner, or by the presence of Wright's wife and children in the photograph as measures of scale. Others can be identified by their style and subject matter, or geographical location, for example one box (Box EB, negatives 1572-1381 to 1572-1390) is labelled "Wellington Views". Intriguingly some of the 380 Henry Wright negatives held by the Alexander Turnbull Library in Wellington are comprehensively annotated with technical data and dates down to the time of day and prevailing weather conditions - not unlike some of Charlie's negatives, such as negative 1572-897 (figure 6) which was taken on 22 January 1906 at 5 o'clock in the afternoon with a very lengthy exposure time of 8 seconds.

There is also a box of 14 glass plates among the 2018 donation marked as being "Harry Bennett's negatives" (Box Y, numbers 1572272 to 1572-285 inclusive). In addition negatives 1572-839A, 1572-907 and 1572-908 are noted has having been purchased from Bennett, a former employee at John Robert Hanna's studio in Auckland. ${ }^{17}$ Several are views of Whakatane, but a series of four shows the opening of the Motukaraka Dairy Factory in October 1908. One of these [1572-840] was published under Bennett's name in the Auckland Weekly News, and other examples of his work printed by the same title suggest he was again active in the Hokianga area in 1913/14. In fact the 1911 electoral roll and 1915 New Zealand Post Office Directory point to Bennett operating a studio in Ivydale directly across the water from Kohukohu for much of this period. ${ }^{18}$

Charlie was also well acquainted with William Gordon-Jones who was noted by the New Zealand Herald as the resident photographic artist in Taheke as early as $1891 .{ }^{19}$ It was an evidently rewarding and enduring friendship. Negative 1572-614 (figure 7) is an undated but youthful portrait of Gordon-Jones who turns up again, this time looking more gaunt than fresh-faced, in the background to two of Charlie's Dog Tax Rebellion photographs [1572-341 and 1572-342, figure 8]. At Charlie's request Gordon-Jones photographed the Dawes family's decayed old house at Punakitere (figure 9) long after they had left for Kohukohu; and a group portrait probably taken towards the end of the first decade of the twentieth century shows Charlie Dawes, his brother Ernie, and William Gordon-Jones as a musical ensemble playing violins and mandolin (figure 10). What is interesting about this photograph, apart from the trio's impressive musical ability, is the painted backdrop. It is quite unusual in that it is a recognisably New Zealand scene, depicting the volcanic cones of Rangitoto, Mount Victoria and North Head, and also including the distinctive outline of the temporary St Paul's Church at the corner of Short Street and Eden Crescent. This replaced the old St Paul's church in Emily Place when it was demolished in 1885 , and served until the new church in Symonds Street was consecrated in 1895. Intriguingly the view is very similar to Charlie's negative 1572432 , the only central Auckland view in the entire collection. So did Charlie purchase the backdrop, or did he paint the backdrop himself based on his own photograph? Or given what is known about his 
acquisition of photographs by other photographers, did he buy the negative and hire someone else to paint the backdrop? Was it even painted contemporaneously with the existence of the temporary St Paul's church or sometime later? It is impossible to say, but what seems clear is that by $1900 / 1$ at the very latest Charlie had acquired various studio trappings and props and made the transition from amateur photographer to taking photographs professionally.

Despite his professional status, however, Charlie's studio would not have matched up to modern expectations. Although many of his portraits show a relatively tidy arrangement, others display evidence of the studio being part of a workshop, with a vice set to one side and wood-shavings spread across the floor and workbench. The workshop was probably located in the large shed to the rear of the Dawes family home (shown in negative 1572-308, figure 11), even though the lack of any obvious light source beyond the standard windows and a glassedin section of verandah would have rendered the premises less than ideal for photographic work. The fact that the property was on the hillside overlooking the Kauri Timber Company wharf makes it unlikely that Charlie would have been the owner of the studio down at the Kohukohu waterfront noted previously. Indeed, even if Charlie found it necessary to reconsider his living arrangements following his marriage to Jessie Allen in 1901, the quayside signboard unequivocally proclaims "Photographers" in the plural which would strongly suggest it was attached to the Northwood Brothers' studio rather than that of a single photographer.

Of course, a photographer was not necessarily limited to a physical studio even when taking formal portraits, and Charlie was no exception. His negatives clearly show that he travelled throughout the Hokianga area and beyond, seizing whatever opportunities for portraiture came to hand. A semi-derelict shed, a farm building or an agricultural fence were easily converted into an open-air studio by hanging up a painted backdrop, a decorative rug or even just a plain sheet; and if his customers were unimpressed by the makeshift nature of their surroundings (as their pained expressions sometimes suggest) (figure 12) once the extraneous elements had been cropped out of the final print Charlie's skill was such that no one would have suspected that the result was not the product of the best of New Zealand studios.

But even irregular working as an itinerant photographer was not easy. Although the introduction of the dry plate negative into New Zealand in the early 1880 s had drastically reduced the paraphernalia a travelling photographer needed to carry with him, Charlie would still have had to lug a substantial amount of bulky equipment including his large, wooden Lancaster camera and tripod, his various backdrops and other props, together with a supply of very heavy glass plates. He would also have had to contend with the sort of adverse conditions that came with travelling along New Zealand's highways at the turn of the century. There are no photographs of Charlie and his camera at work in the field, but two portraits of the surveyor Jack Stevens standing with his theodolite up to his knees in mud give some idea of the type of adversities Charlie may have had to endure (figure 13).

Charlie Dawes initially saw himself as a purely amateur photographer, but he did not operate in seclusion. Despite its geographical remoteness, Kohukohu was far from being a cultural backwater. Charlie's notes show that he shared his lenses not just with Daniel Warren, but also with the microscope slide maker and camera enthusiast William Low Sarjeant who had left his home in Croydon, Surrey in 1895 and set himself up in Kohukohu as a watchmaker and watch repairer. ${ }^{20}$ Charlie clearly relished contact with other photographers, whether resident or just passing through, and happily exchanged guidance and advice, perhaps even receiving some training from the likes of Enos Pegler, Henry Wright, Daniel Warren, and William Gordon-Jones, amongst others. ${ }^{21} \mathrm{He}$ was plainly excited by photography and photographic processes, and by photographic technology and equipment, to the extent that he would not infrequently record which type of lens he was using, and gave specific instructions in his will as to who was to inherit his camera after his death. ${ }^{22}$

Although a number of his photographs appeared in

publications such as the Auckland Weekly News and New Zealand Graphic, most of his photographs had a limited commercial value and were taken primarily for his own interest. He took numerous photographs of the communities of the Hokianga, and whether it was his intention or not he created an invaluable and historically important record of the townships of Kohukohu and Rawene in particular (figure 14). Many of the portraits he took are of his wife Jessie, his children, and of his parents and extended family. Surprisingly Charlie also appears himself in quite a few of them (figures 15 and 16), meaning that even if he set up the shot, someone else must have operated the camera. Whether this was his brother Ernie, his wife Jessie, or one of his children or step-children is unknown.

The 2018 donation of Dawes negatives has produced a great deal of additional information about Charlie Dawes as a photographer; but it has also undermined some of the original conclusions made 
about him and raised more questions about how and why he took up photography. The collection as a whole gives a remarkable insight into Charlie's life and work, and the circle of friends and acquaintances that influenced and assisted him. Its make-up also holds out the possibility that there may be further examples of Charlie's work still to be

discovered which might add to our knowledge. Regardless of whether such material comes to light, ultimately there is still more research that needs to be done before we can provide definitive answers about the career of this remarkable photographer. ${ }^{23}$

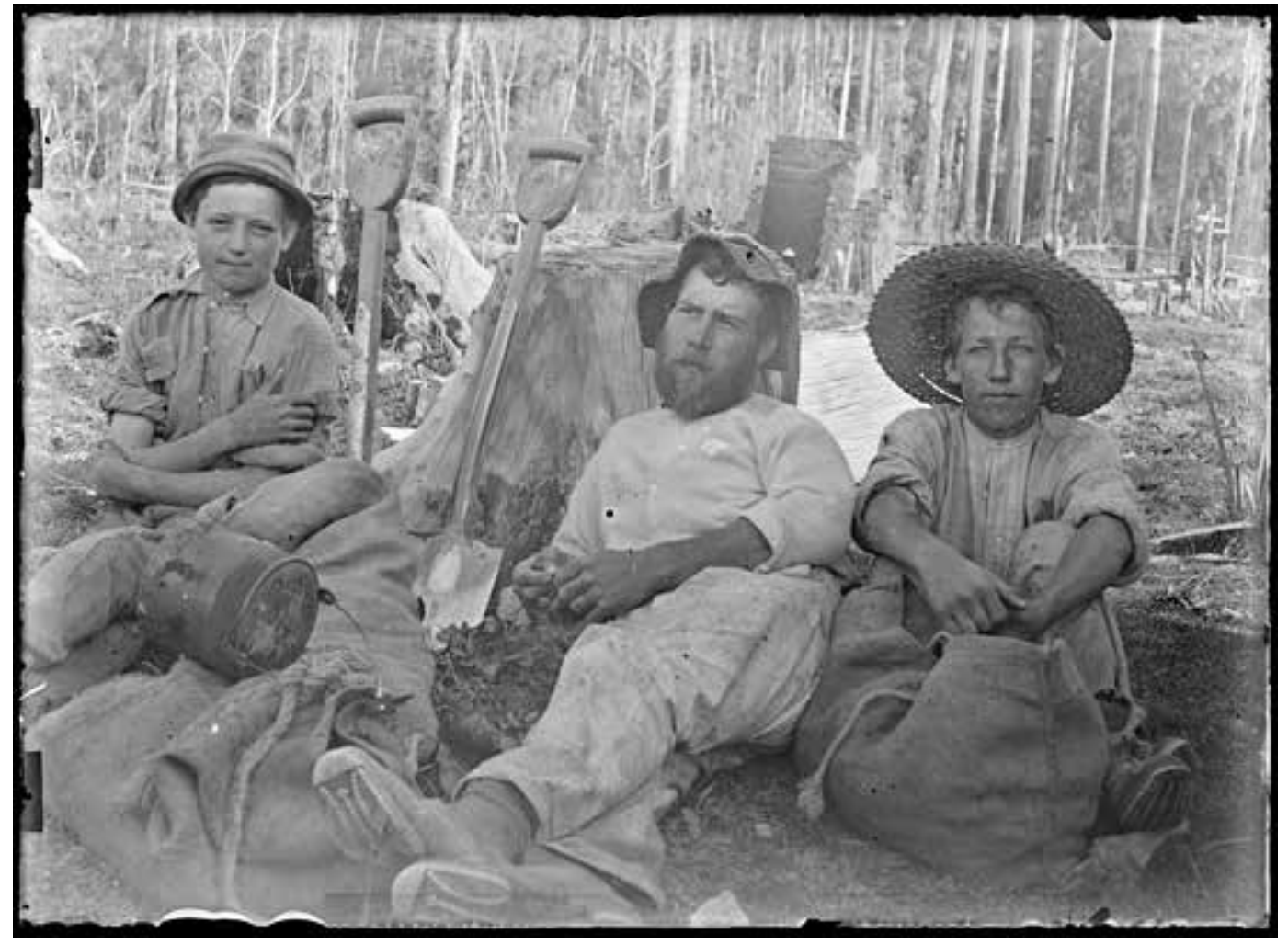

Figure 1, C P Dawes. "Ernie, Jack \& Dugmore 1st attempt": Edwin Dugmore with the beard (centre), Jack Josephs (left), and Charlie's brother Ernie. Probably Charlie's first ever photographic effort, 1888. Auckland Libraries Heritage Collections, 1572-1115

Following spread: Figure 4, C P Dawes. The Photographer's Tent. Auckland Libraries Heritage Collections, 1572-1220. Note that this is a double exposure; a cleaned up version was used in the Auckland Libraries' exhibition: 'Charlie Dawes: Everybody's Artist Photographer' which ran from May to August 2019. Enos Pegler is holding the camera (left), and Charlie Dawes is standing next to the sample board (centre).

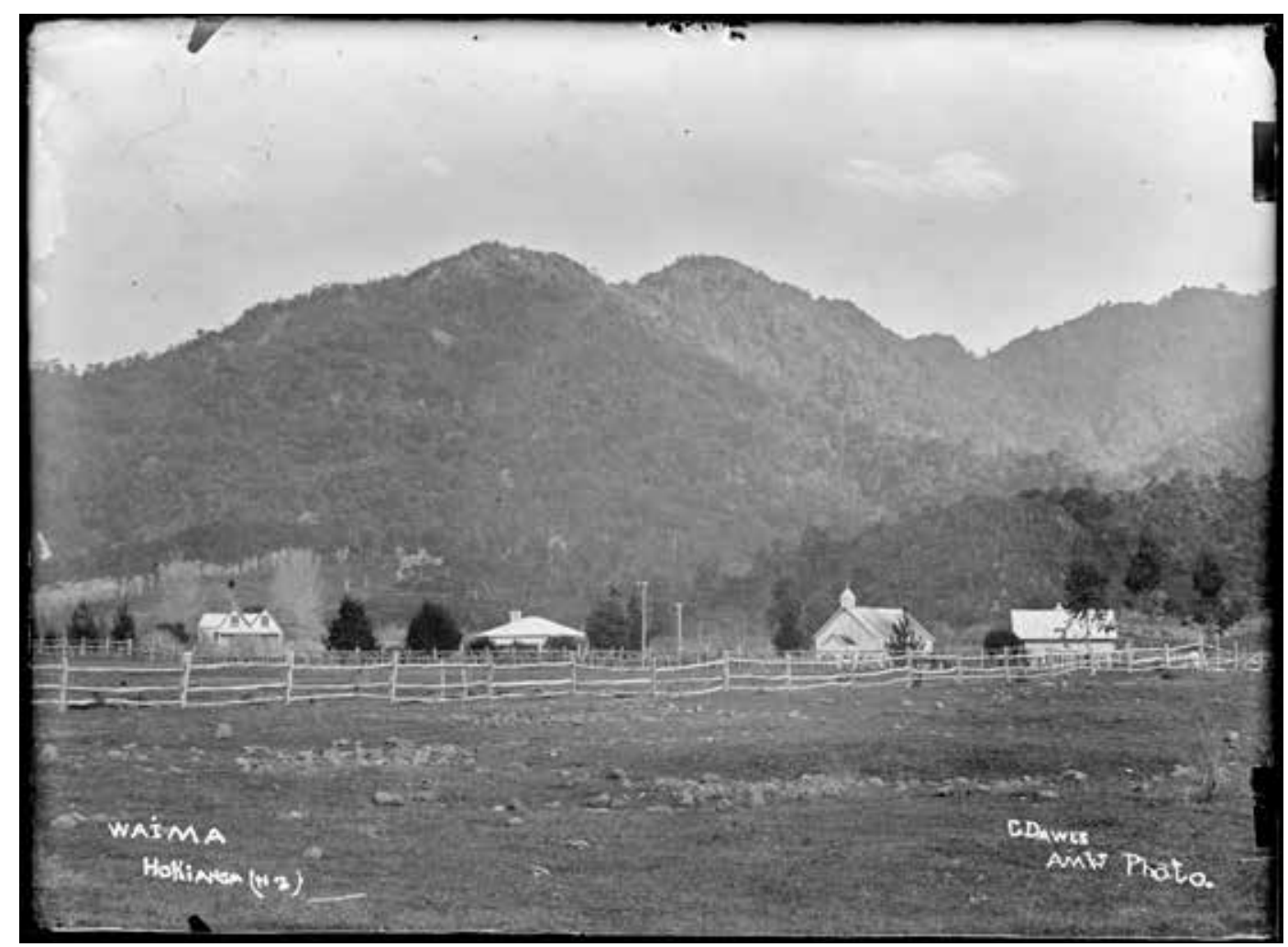

Figure 3, C P Dawes. "Waima Hokianga (NZ) C Dawes Amtr Photo." Auckland Libraries Heritage Collections, 1572350. A cropped version of this photograph was published in the New Zealand Graphic of 28 May 1898 to accompany other photographs from the Dog Tax Rebellion. Negative 1572-351 shows a similar view and includes soldiers arrayed in front of the church, but the editor obviously preferred this shot because the trees are smaller and the buildings less obscured. This would therefore appear to be an example of Charlie, like his friend Enos Pegler, supplying for publication a photograph that pre-dated the unrest.

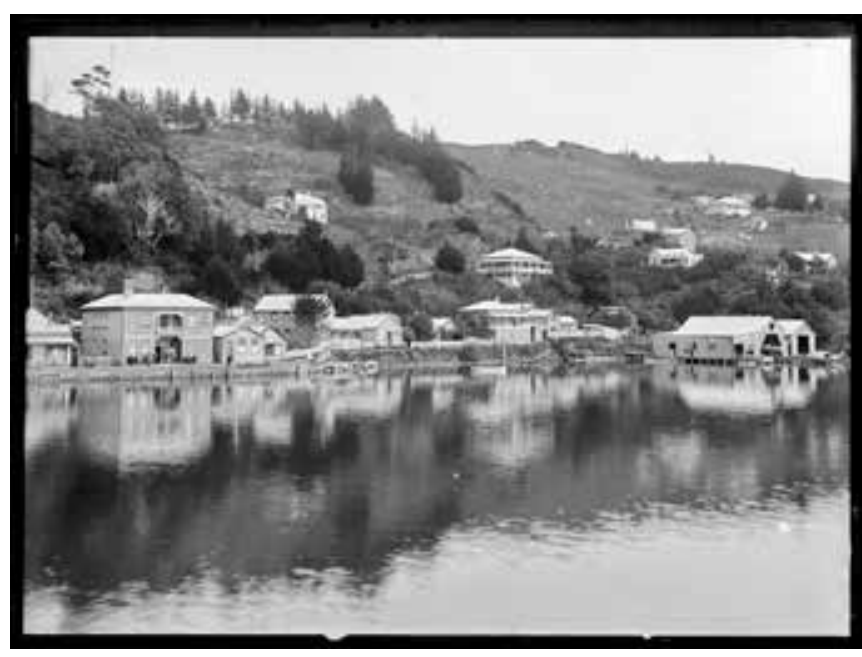

Figure 2, C P Dawes. Kohukohu waterfront, probably photographed around 1910. Auckland Libraries Heritage Collections, 1572-953. This was the first of the 1670 glass plate negatives cleaned in December 2018. There is a photographer's signboard a the far end of the quay. 


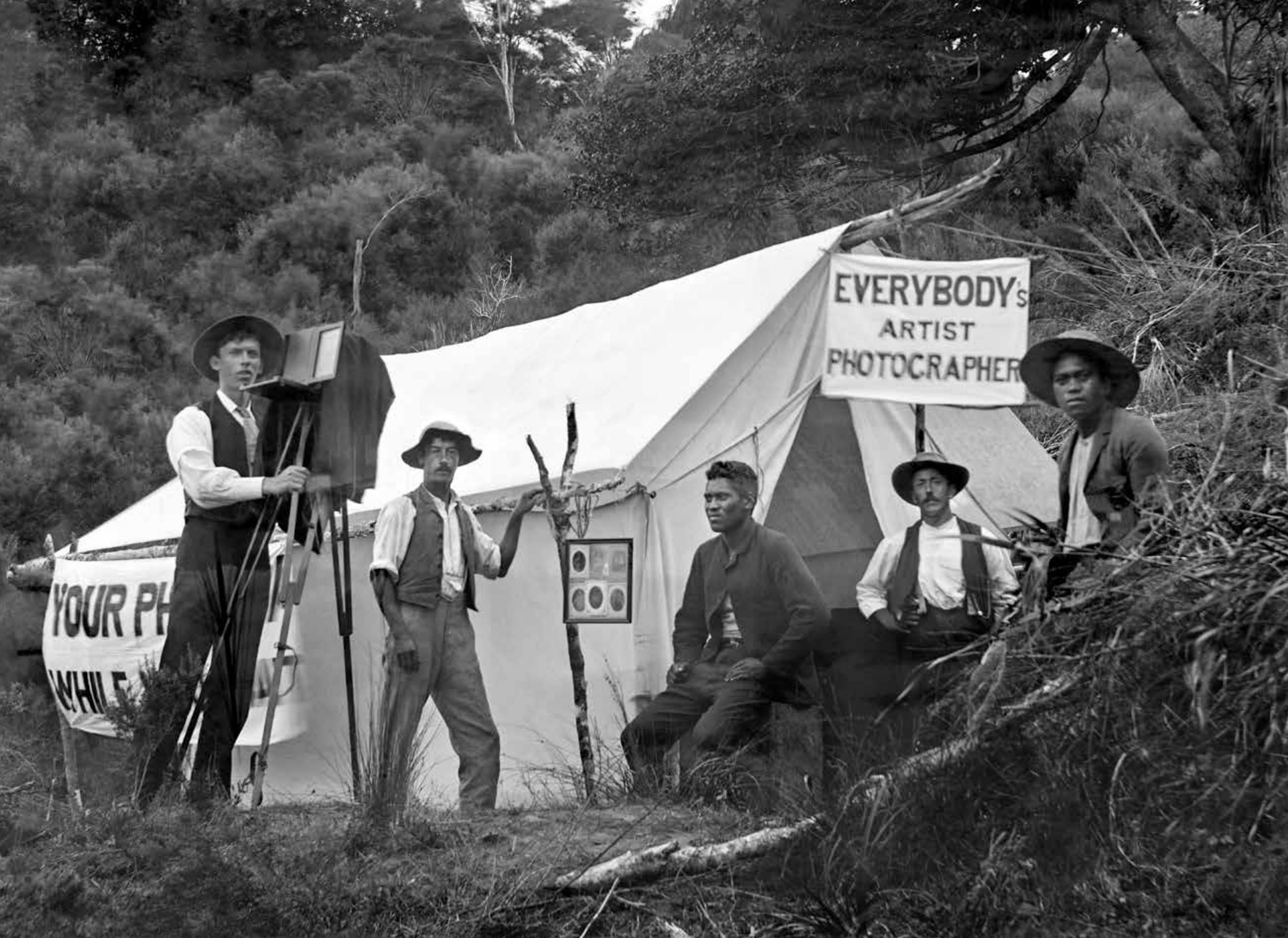




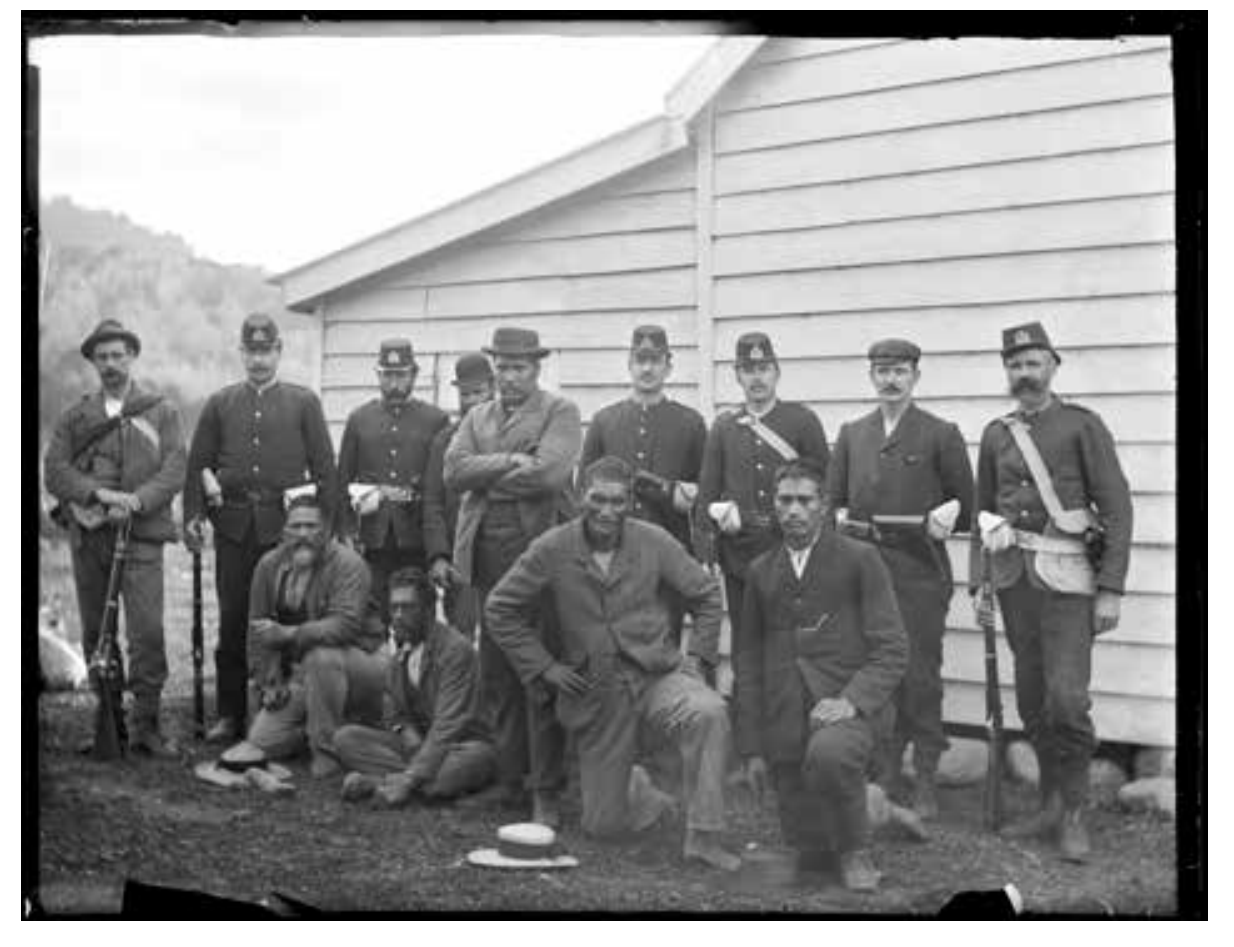

Figure 5, C P Dawes. Charlie's most recognisable photograph - soldiers guarding the arrested leaders of the so-called 'Dog Tax Rebellion', May 1898. From left to right: Romana Te Paehangi, Hone Mete, Hone Toia (standing), Wiremu Te Makara, and Rakene Pehi. Auckland Libraries Heritage Collections, 1572-425.

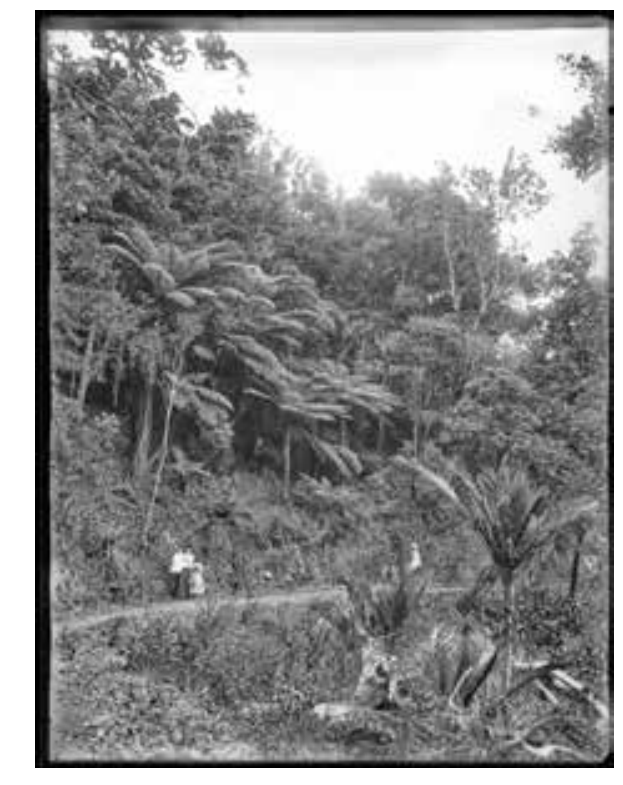

Figure 6, C P Dawes. Charlie's wife Jessie with Charlie's notes the photograph was taken on 22 January 1906 at 5 o'clock in the afternoon Libraries Heritage Collections, 1572-897. their daughters Christina May and Rache on Lovers' Walk, Kohukohu. According to

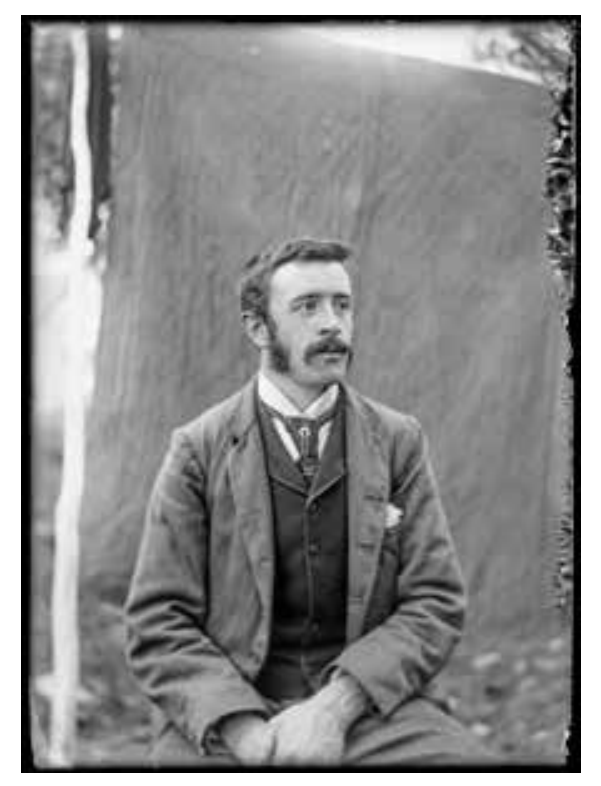

Figure 7, C P Dawes. Photographer and friend, William Gordon-Jones. Auckland Libraries

Heritage Collections, 1572-614.

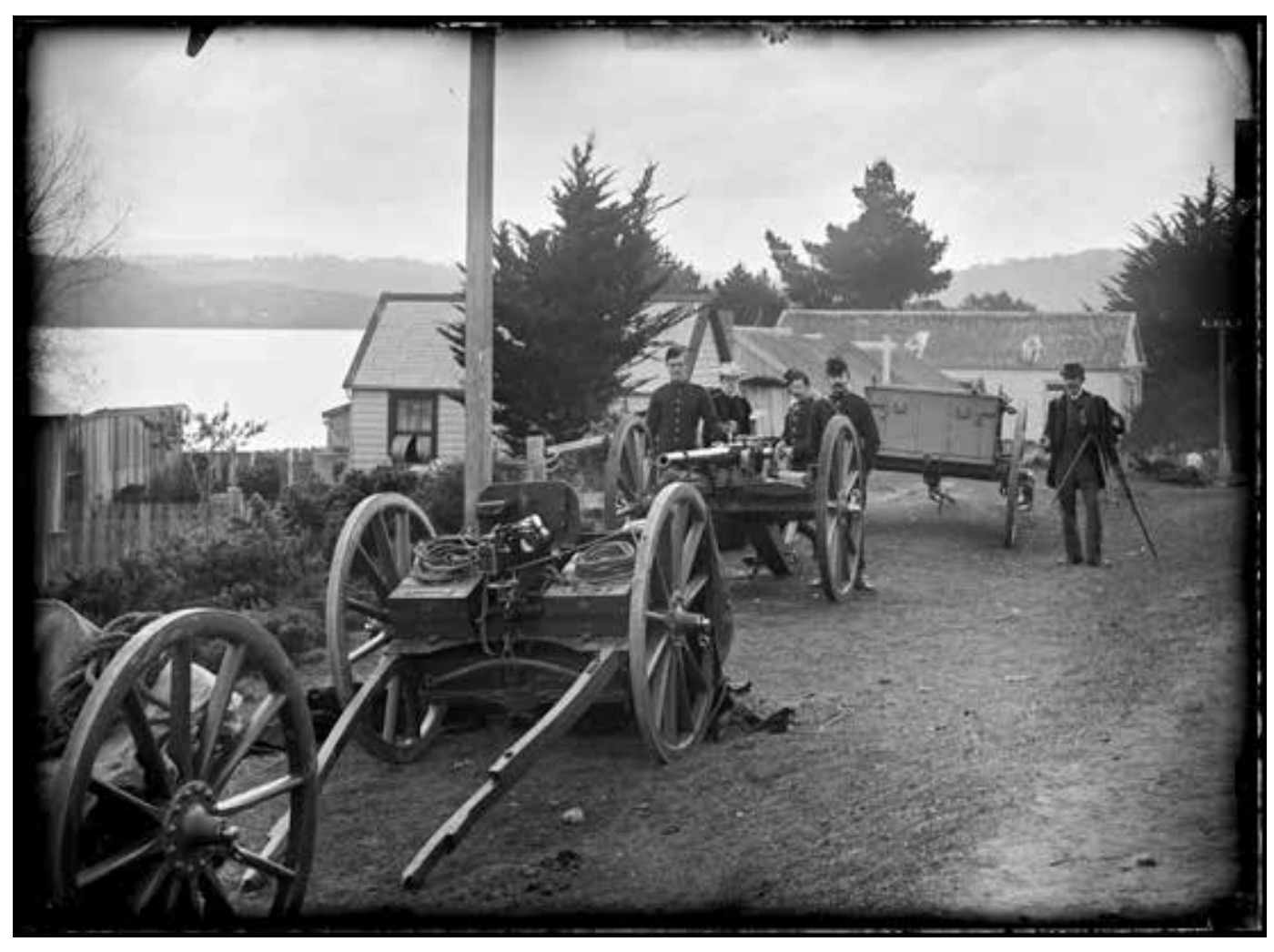

Figure 8, C P Dawes. "Artillery and W Jones": William Gordon-Jones with his camera at Rawene during the Dog Tax Rebellion, May 1898. Auckland Libraries Heritage Collections, $1572-342$. 

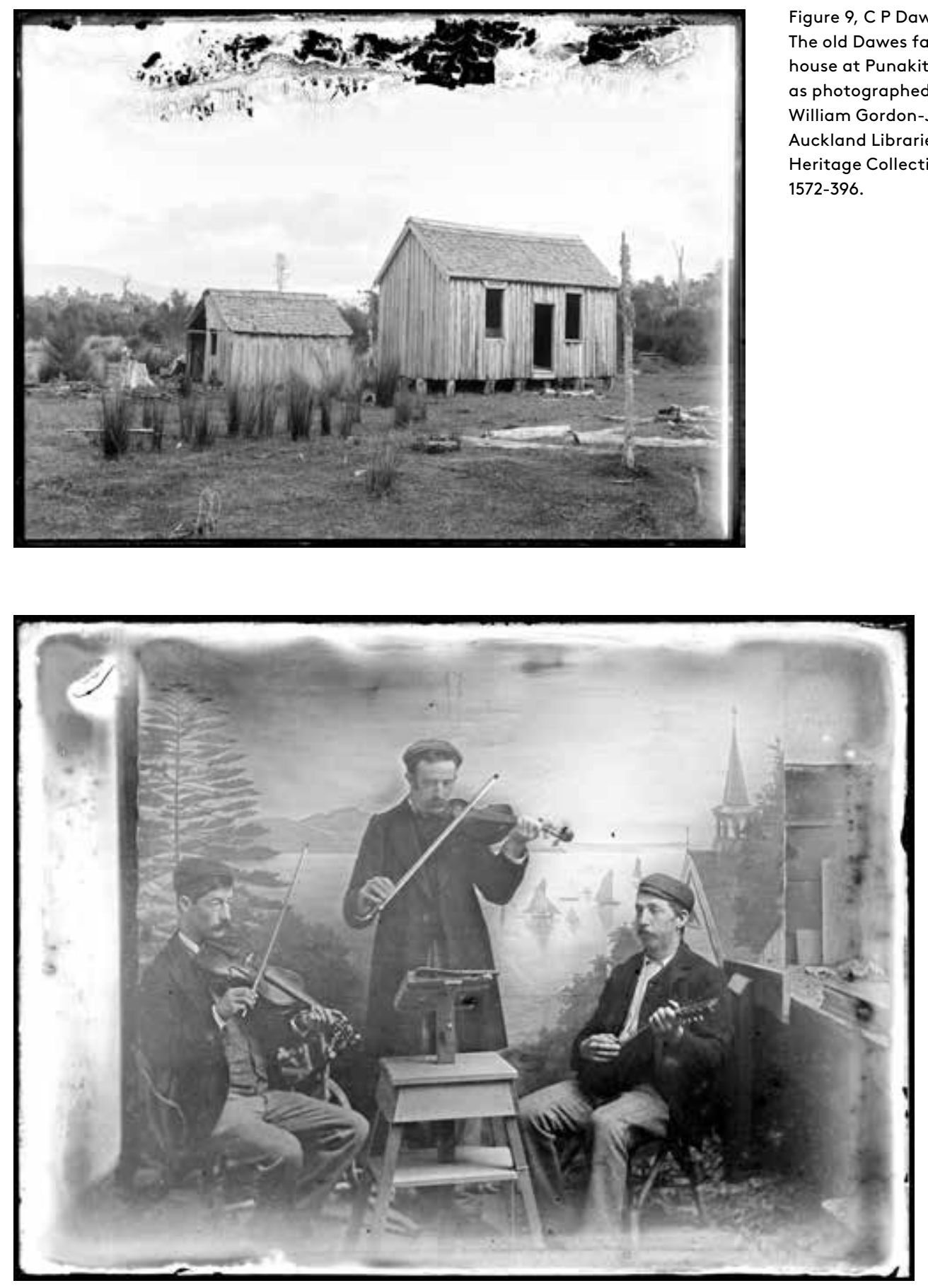

Figure 10, C P Dawes. Musical ensemble: Charlie Dawes (left), William Gordon-Jones (centre), Ernie Dawes (right). Auckland Libraries Heritage Collections, 1572-457. The painted backdrop shows Auckland Harbour and Rangitoto, and the spire of the temporary St Paul's church (right). The studio clearly shares its space with a busy carpenter's workshop: a vice and workbench can be seen over Ernie's left shoulder.
Figure 9, C P Dawes. The old Dawes family house at Punakitere, as photographed by William Gordon-Jones.
Auckland Libraries Auckland Libraries 1572-396.

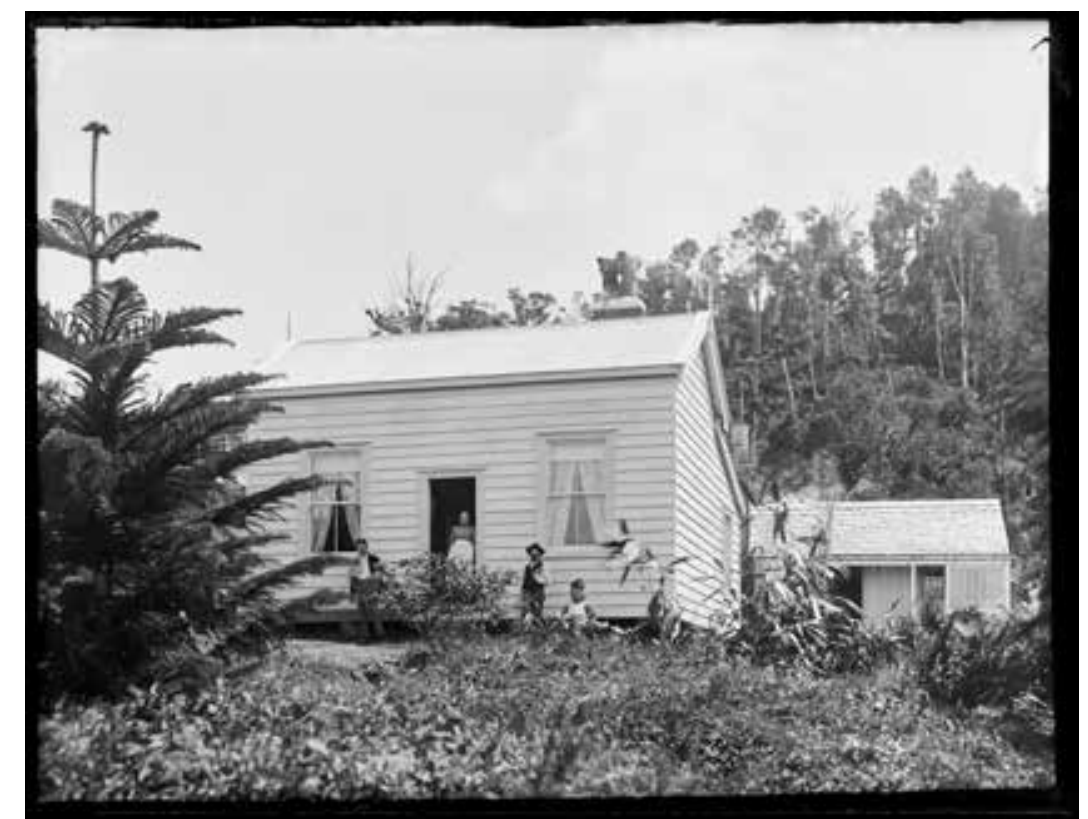

Figure 11, C P Dawes. The Dawes family house at Kohukohu, probably around 1900 Charlie's photographic studio may have been in the shed at the back. Auckland Libraries Heritage Collections, 1572-308.

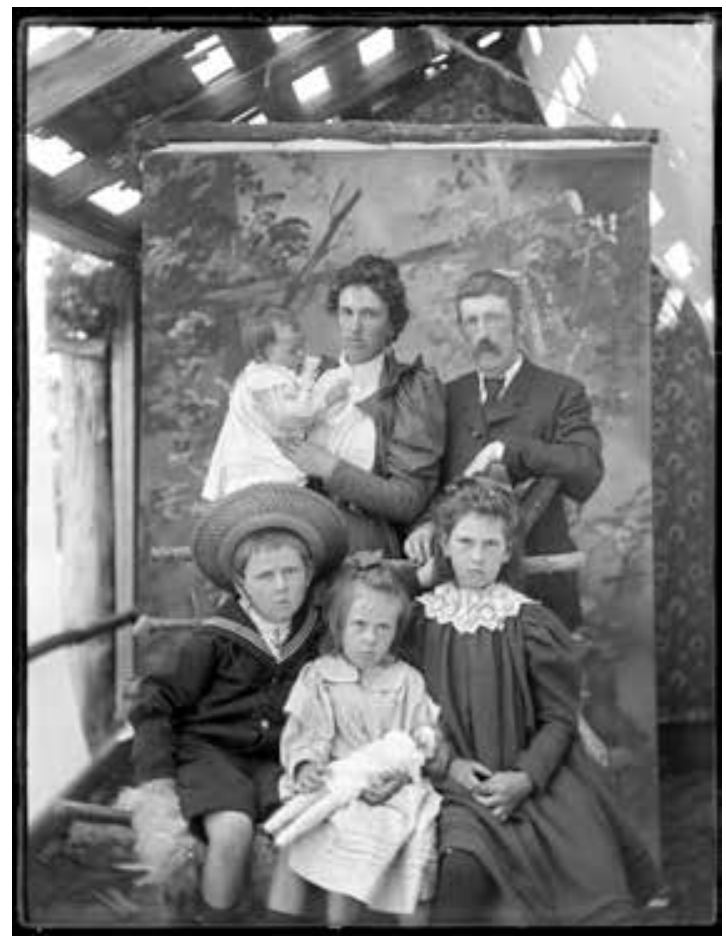

Figure 12, C P Dawes. The Carse family of Kaiakd, near Kaitaia, circa 1900, looking less than happy with their photographic experience. Auckland Libraries Heritage Collections, 1572-1632. 


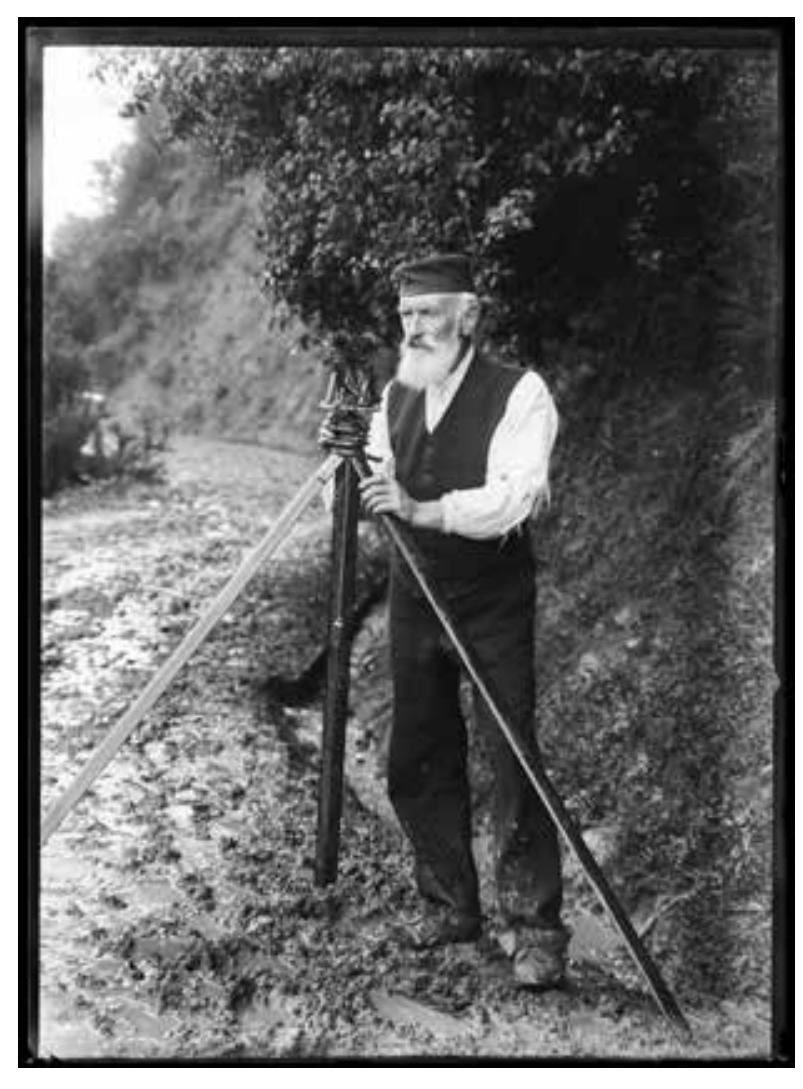

Figure 13, C P Dawes. Broadwood surveyor

Jack Stevens, undaunted by the road

conditions in the Hokianga. Auckland

Libraries Heritage Collections, 1572-1146.

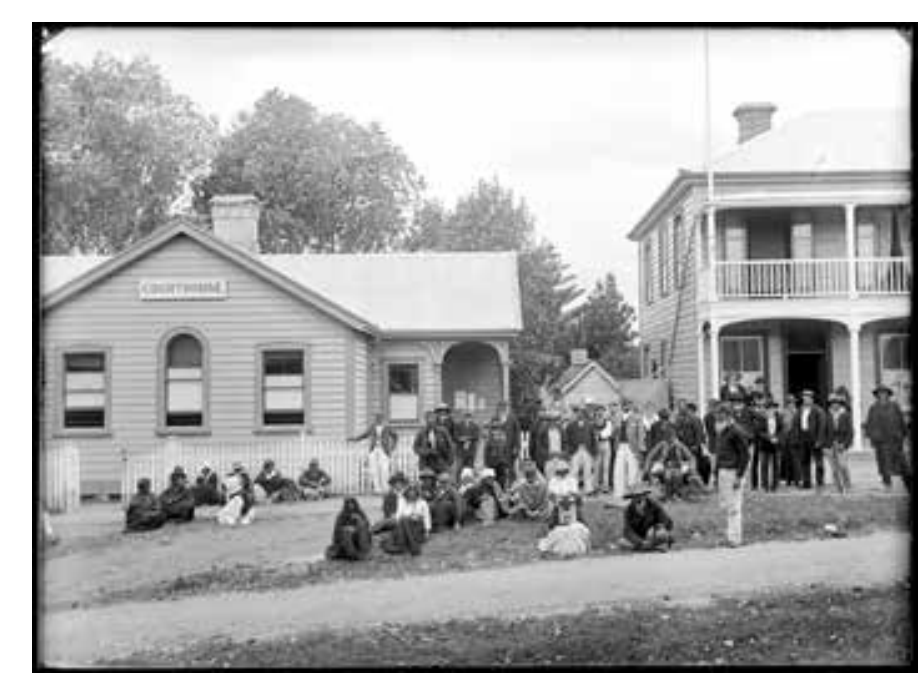

Figure 14, C P Dawes. Maori applicants for the means-tested Old Age Pension outside the courthouse (left) and Masonic Hotel (right) in the main street at Rawene, part of a photographic essay by Charlie Dawes published in the New Zealand Graphic in March 1899. Auckland Libraries Heritage Collections, 1572-1084

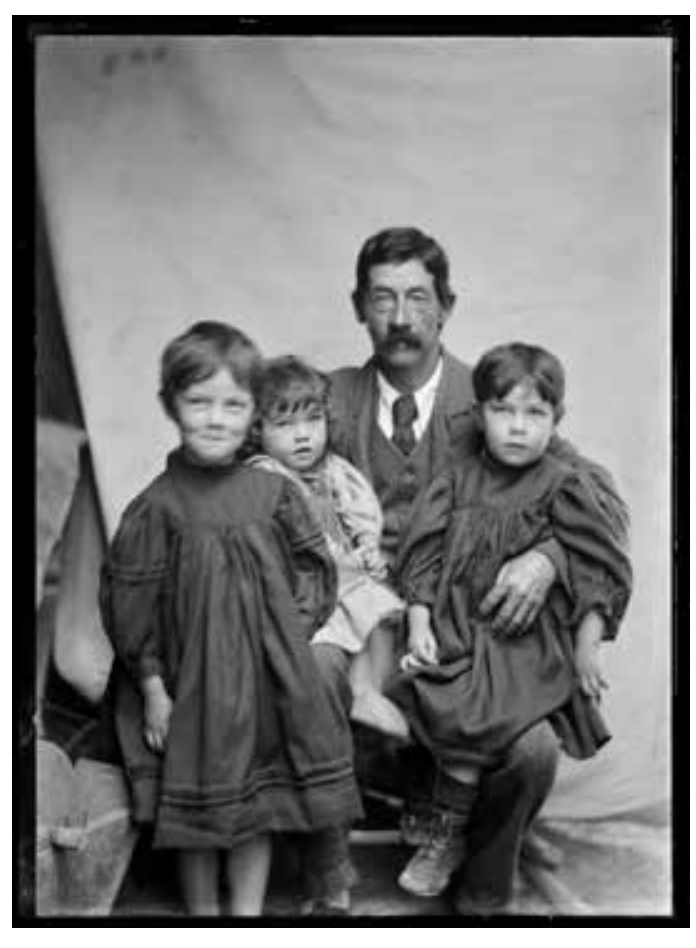

Figure 15, C P Dawes. Charlie Dawes with three of his daughters, Ada An (left), Pearl (centre) and Christina May, about 1909. Auckland Libraries Heritage Collections, 1572-1505.

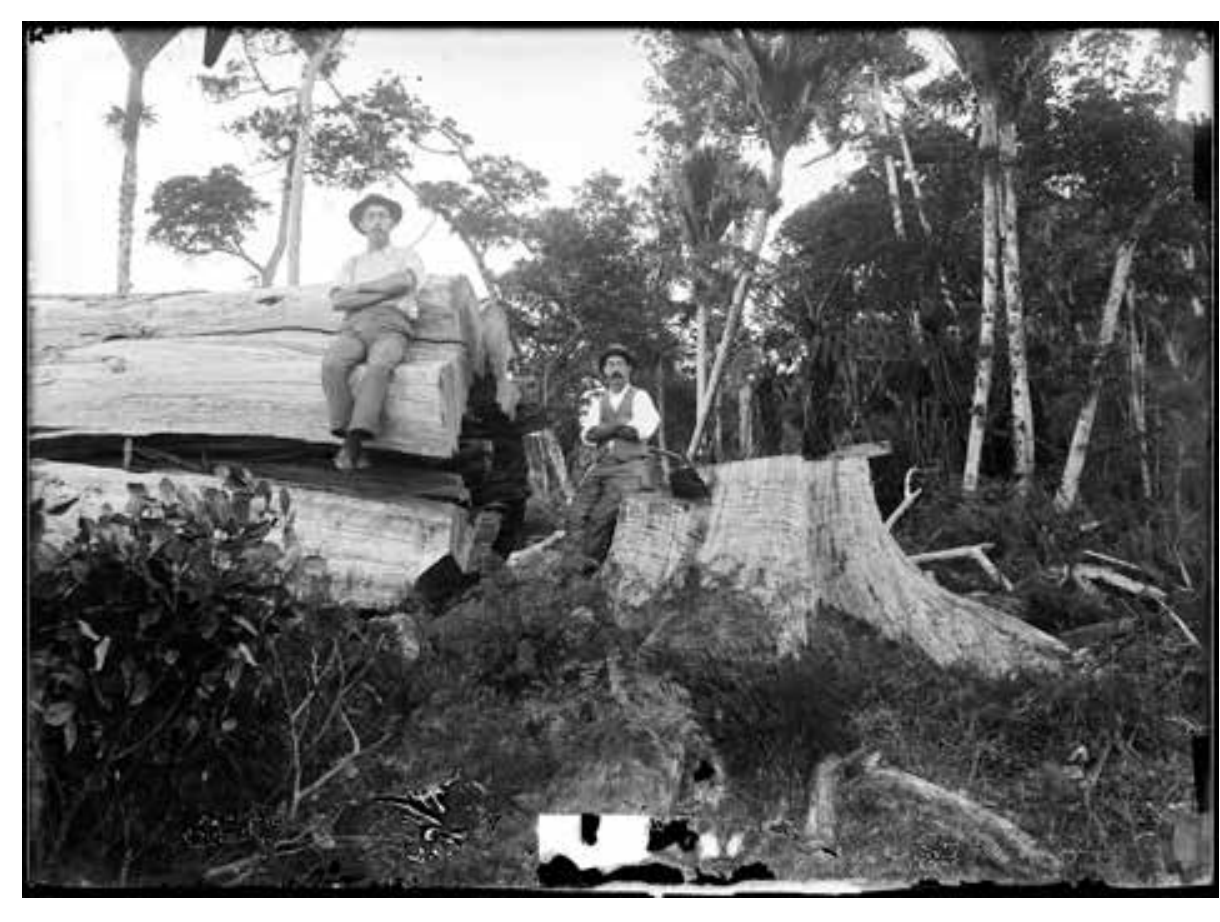

Figure 16, C P Dawes. Charlie and Ernie Dawes (left) sitting on the remains of a felled hollow puriri, circa 1910. Auckland Libraries Heritage Collections, 1572-389. 


\section{REFERENCES:}

1861 England census for Newhall, Derbyshire (RG9/1693, fo.98v).

1911 Electoral District of Bay of Islands, General

Archives New Zealand. Whangarei Probates: Dawes, Charles Peet. BBNY 10297 A1346 44/1302

Auckland Star, "Untitled," August 8, 1890: 2.

Auckland Star, "The Hokianga War," May 7, 1898:

Auckland Star, "Deaths," September 5, 1908: 10.

Auckland Weekly News photographic

supplements -http://www.aucklandcity.govt.nz/

dbtw-wpd/heritageimages/index.htm

Auckland Weekly News, "The Prisoners

Photographed," May 14, 1898: 3.

Bay of Plenty Times, "Up-to-date Photography," January 17, 1908: 3.

Births, Deaths and Marriages on-line http://www. bdmhistoricalrecords.dia.govt.nz

Dragicevich, Kaye. "Beautiful photographs of early Hokianga by Charlie Dawes." Doubtless Bay Times, October 21, 2009: 5 .

Fine Arts Copyright Act 1877 (41 Victoriae 1877 No 17)

Giles, Keith. "C P Dawes Collection." New Zealand Legacy 24, no.2 (2012): 12-14.

Harrison, Eric, Kohukohu. Kamo, New Zealand: Kamo Print Limited, 1983.

Manawatu Herald, "Untitled," August 31, 1905: 2.

New Zealand Graphic photographs -http://www. aucklandcity.govt.nz/dbtw-wpd/heritageimages/

\section{index.htm}

New Zealand Herald, "Village Settlement Scheme," September 7, 1886: 2.

New Zealand Herald, "Auckland Photographic Exhibition," April 7, 1891: 6.

New Zealand Herald, "Taheke," July 3, 1891: 6

New Zealand Herald, "Untitled," September 4 1891: 5 .

New Zealand Herald, "Births, Marriages, Deaths," May 27, 1903: 11 .

Otago Witness, "Cattle crossing a stream near Mongonui, Auckland," August 12, 1903:38.

Otago Witness, "A view in Whangaroa," September 14, 1904: 46.

Patea Mail, "Photography," September 5, 1877: 1. Patea Mail, “D M Warren," November 30, 1881: 1. Photographic Copyright Act 1896 (60 Victoriae 1896 No 16)

Stevenson, Brian. "Slide maker 'WLS', probably William Low Sarjeant, 1851-1924." http:// microscopist.net/WLS.html [accessed September 15, 2019].

Sullivan, John. "The Henry Wright Collection of photographic negatives." The Turnbull Library Record 12, no.1 (1979): 37-44.

Wise's New Zealand Post Office Directory. New Zealand: H Wise \& Co, 1915

The Dawes Collection can be searched on-line athttps://kura.aucklandlibraries.govt.nz/digital/

\section{ENDNOTES}

1 The work of Charlie Dawes is represented in the Drummond- Te Wake Collection at Whangarei Art Museum; and the Auckland War Memorial Museum has 93 Dawe negatives previously held by the Waihi Museum.

2 New Zealand Herald, "Village Settlement Scheme," September 7, 1886: 2; Keith Giles, "C P Dawes Collection." New Zealand Legacy 24, no.2 (2012): 12

3 This is based on New Zealand death registration 1939/17169 for John William Josephs.

4 Kaye Dragicevich, "Beautiful photographs of early Hokianga by Charlie Dawes." Doubtles Bay Times, October 21, 2009: 5.

5 Manawatu Herald, "Untitled," August 31, 1905: 2.

6 Wise's New Zealand Post Office Directory (New Zealand: H Wise \& Co, 1915), p457.

7 Otago Witness, "Cattle crossing a stream near Mongonui, Auckland," August 12, 1903:38; Otago Witness, "A view in Whangaroa," September 14, 1904: 46.

8 New Zealand Herald, "Auckland Photographic Exhibition," April 7, 1891: 6, and see below.

9 Eric Harrison, Kohukohu (Kamo, New Zealand: Kamo Print Limited, 1983), p25.

10 Their son, Sammy, was actually born at his grandmother's house in Victoria Street, Onehunga in 1903, see New Zealand Herald, "Births, Marriages, Deaths," May 27, 1903: 11; and Sammy's death notice (in the Auckland Star, "Deaths," September 5 , 1908: 10) confirms the Onehunga-Kohukohu connection.

11 Auckland Star, "Untitled," August 8, 1890 2. Pegler repeated the lecture in 1891 , this time dwelling on the "rough voyage from the Manukau to the Hokianga Heads" (New Zealand Herald, "Untitled," September 4, 1891: 5).
12 Auckland Star, "The Hokianga War," May 7, 1898: 8.

13 Auckland Weekly News, "The Prisoners Photographed," May 14, 1898: 3.

14 Patea Mail, "Photography," September 5, 1877: 1; Patea Mail, "D M Warren," November 30, 1881: 1.

151911 Electoral District of Bay of Islands, General Roll, p119.

16 John Sullivan, "The Henry Wright Collection of photographic negatives," The Turnbull Library Record 12, no.1 (1979): 42; dates are taken from the National Library website https:// natlib.govt.nz/ [accessed September 16, 2019].

17 Bay of Plenty Times, "Up-to-date Photography," January 17, 1908: 3.

181911 Electoral District of Bay of Islands, General Roll, p9; Wise's New Zealand Post Office Directory (New Zealand: H Wise \& Co, 1915), p2135.

19 New Zealand Herald, "Taheke," July 3, 1891: 6.

20 Brian Stevenson, "Slide maker 'WLS', probably William Low Sarjeant, 1851-1924," http:// microscopist.net/WLS.html [accessed September 15, 2019].

21 The photographer $\mathrm{H}$ Kelsey may be related to the Kelsey family of Motukaraka (see negative 1572-744) and could also have been a member of Charlie's photographic cabal. Examples of his work can be seen in the Auckland Weekly News in 1904 and 1919/20.

22 Probate records for Charles Peet Dawes, Archives New Zealand ref. BBNY 10297 A1346 44/1302.

23 For instance there is a suggestion that Charlie may have been introduced to photography by his uncle and namesake, Charles Dawes, who appears in the 1861 census for Newhall, Derbyshire (RG9/1693, fo.98v) as a "grocer and druggist" 